\title{
Heavy Metals in an Urban Watershed in Southeastern Michigan
}

\author{
Kent S. Murray,* Daniel T. Rogers, and Martin M. Kaufman
}

\begin{abstract}
The occurrence of heavy metals in the soil was measured over a period of several years to determine background concentrations in a heavily urbanized watershed in southeastern Michigan. A spatially dispersed sample was collected to capture the inherent variability of the soils and historic land use. The analysis focused on 14 metals (antimony, arsenic, barium, beryllium, cadmium, chromium, copper, lead, mercury, nickel, selenium, silver, thallium, and zinc) that are part of the USEPA's list of the 129 most common pollutants. Metal concentrations were measured at three depths: near-surface $(<0.5 \mathrm{~m})$, shallow subsurface $(0.5-10 \mathrm{~m})$, and depths greater than $10 \mathrm{~m}$ across six soil units in glacial terrain. Additional analyses assessed the metal concentrations in each depth profile across three general land use categories: residential, commercial, and industrial. Metal concentrations were the highest in the near-surface with $\mathrm{Pb}$ present at concentrations averaging 15.5 times that of background in industrial areas and approximately 16 times background in residential areas. Cadmium, $\mathrm{Hg}$, and $\mathrm{Zn}$ were also present in surface soils at levels of several times that of background. The highest concentrations of each of these metals were present in the clay-rich soils located in the eastern, more urbanized and industrialized part of the watershed. Metals detected at elevated concentrations decreased in concentration with increasing depth and distance from the urbanized and industrialized center of the watershed. Statistically significant differences in the concentrations of heavy metals were also noted between the land use categories, with $\mathrm{Cd}, \mathrm{Cr}, \mathrm{Cu}, \mathrm{Pb}, \mathrm{Ni}$, and $\mathrm{Zn}$ observed within industrial areas at mean concentrations several times greater than background levels.
\end{abstract}

$\mathrm{H}$ EAVY METALS NATURALLY OCCUR in the environment, but may also be introduced as a result of land use activities. Naturally occurring as well as anthropogenically introduced concentrations of metals in near-surface soil can vary significantly due to different physical and chemical processes operating within soils across geographic regions. Historically, soil scientists and geologists have studied near-surface soil for agricultural or farming purposes to better understand natural ecosystems (Thornton, 1991), or focused on the health effects in urban areas associated with one or two metals (Mielke et al., 1983). As a result, there is little information available on the background level of metals in the nearsurface soil in urban areas. In 1984, the United States Geological Survey (USGS) conducted a 20-year investigation of surface soils within the conterminous United States that included the 14 metals considered in this study (Shacklette and Boerngen, 1984). In 1995, Cox and Colvin conducted a study of heavy metals in Ohio using heavy metal concentrations collected according

K.S. Murray, Department of Natural Sciences, University of MichiganDearborn, Dearborn, MI 48128. D.T. Rogers, Amsted Industries, Chicago, IL 60601. M.M. Kaufman, Department of Earth and Resource Science, University of Michigan-Flint, Flint, MI 48502. Received 1 Feb. 2003. *Corresponding author (kmurray@umich.edu).

Published in J. Environ. Qual. 33:163-172 (2004).

(c) ASA, CSSA, SSSA

677 S. Segoe Rd., Madison, WI 53711 USA to Ohio Environmental Protection Agency guidelines at 52 Resource Conservation and Recovery Act (RCRA) sites located throughout the state to evaluate naturally occurring heavy metal concentrations. The Cox and Colvin study was a regional study designed to evaluate naturally occurring background concentrations but did not differentiate between different soil types. In Michigan, evaluations of metals in soil have been conducted by the Michigan Department of Natural Resources (1991) and Kesler-Arnold and O'Hearn (1990). Although these latter two studies included southeastern Michigan, their evaluation of the naturally occurring concentrations of metals in the soil was restricted to rural areas of the state. Holmgren et al. (1993) evaluated the concentrations of $\mathrm{Cd}, \mathrm{Pb}, \mathrm{Zn}, \mathrm{Cu}$, and $\mathrm{Ni}$ in agricultural soils of the country and Miller and McFee (1983) focused on $\mathrm{Cd}, \mathrm{Zn}, \mathrm{Cu}$, and $\mathrm{Pb}$ in industrial soils of northwestern Indiana. More recently, Ma et al. (1997) statistically analyzed the concentrations and distributions of 11 metals in Florida soils, and Alkhatib and O'Connor (1998) studied background levels of priority pollutant metals in surficial soils from 106 urban and non-urban sites in Rhode Island. The Rhode Island study, which used data obtained from the investigation of sites of environmental concern, suggested that elevated concentrations of specific metals such as $\mathrm{Sb}, \mathrm{Hg}$, $\mathrm{Se}, \mathrm{Ag}$, and Tl were probably the result of anthropogenic effects, while the occurrence of the more common metals in Rhode Island soils (As, $\mathrm{Ba}, \mathrm{Be}, \mathrm{Cr}, \mathrm{Cu}, \mathrm{Pb}, \mathrm{Ni}$, and $\mathrm{Zn}$ ) was probably the result of nature.

Our study focuses on the Rouge River watershed located in southeastern Michigan, a highly urbanized area, which includes the city of Detroit. Because of its industrial base, the area contains thousands of known sites of environmental concern, many of which are currently undergoing hazardous site investigations to determine the background levels of metals in the soil (Michigan Department of Environmental Quality, 1998). Although this large number of investigations is not unusual for older urban areas in the eastern United States, the contamination of urban soils can pose a significant threat to human health. Considering that the majority of the U.S. population lives in these areas, this is a significant concern. Yet, the characterization of these soils has always posed a difficult challenge. Urban soils have the greatest potential to be disturbed by human activity, complicating site investigations; more importantly, background information is limited, and, as pointed out by Alkhatib and O'Connor (1998), the cost of analyzing soil samples discourages investigators from taking additional background samples. While the USGS and Michigan Department of Natural Resources (MDNR) studies

Abbreviations: ANOVA, analysis of variance; MDEQ, Michigan Department of Environmental Quality; MDNR, Michigan Department of Natural Resources. 
represent a good first step in solving this problem within Michigan, more detailed work needs to be accomplished at small geographic scales. The goal of this project is to develop a large-scale, watershed-level approach to understanding the background levels of metals in both the near-surface and subsurface soils in the urban environment of southeastern Michigan. The watershed approach is selected because many of the processes that contribute to the occurrence and distribution of metals in the soils of an urban environment (movement of water, location of industry) are closely tied to drainage patterns. Consequently, the watershed concept has become a key factor in modern urban planning (Murray and Rogers, 1999; Wayne County Department of Environment, 1994). Specific objectives of this study were to determine if there are statistically significant differences between the metal concentrations (i) in surface and near-surface soils ( $<0.5 \mathrm{~m}$ in depth), shallow subsurface soils (0.5-10 $\mathrm{m}$ in depth), and soils at depths greater than $10 \mathrm{~m}$; (ii) among the various soil types related to the glacial history of southern Michigan; and (iii) among major land use designations, such as residential, commercial, and industrial properties. It is important to note that the goal of the study is to evaluate the background concentration of metals in the soil in an urban environment, not the naturally occurring concentration of metals in the soil. Sites selected for this study included parks, elementary and high schools, community colleges, churches, banks, new residential developments as well as older residences, courthouses, town hall, law firms, malls, golf courses, vacant property, and industrial properties.

Metals naturally occur in soil in one or more of seven different ways: (i) dissolved in soil solution, (ii) occupying exchange sites on inorganic constituents, (iii) adsorbed in inorganic constituents, (iv) associated with insoluble soil organic matter, (v) precipitated as pure mixed solids; (vi) as secondary minerals; and (vii) in the structure of primary minerals. The metals that have been introduced into the environment through human (anthropogenic) activities are associated with the first five (Shuman, 1991).

Migration of metals in soil is influenced by physical and chemical characteristics of each specific metal and by several environmental factors. The most significant environmental factors appear to be (i) soil type, (ii) total organic content, (iii) redox potential, and (iv) $\mathrm{pH}$ (McLean and Bledsoe, 1992; Jaagumagi, 1993; Murray et al., 1999). Metals in soil solution also migrate through mass transfer by leaching to ground water, plant uptake, and volatization, which are important migration mechanisms when considering the mobility of $\mathrm{As}, \mathrm{Hg}$, and $\mathrm{Se}$ (Mattigod et al., 1981).

With respect to soil type and organic content, clayrich soils generally have a higher retention capacity than soils with little or no clay (e.g., soils composed primarily of sand). Soils with a high organic content also have a higher retention capacity than soils with a lower relative organic content (Stevenson, 1991). Oxidizing conditions generally increase the retention capacity of metals in soil, while reducing conditions will generally reduce the retention capacity of metals (McLean and Bledsoe, 1992). In terms of $\mathrm{pH}$, cationic metals, which include $\mathrm{Pb}, \mathrm{Cu}, \mathrm{Ni}$, and $\mathrm{Zn}$, have a higher retention capacity in soil with a $\mathrm{pH}$ greater than 7 compared with soils with a pH less than 7 (Harter and Lehmann, 1983; Lindsay, 1979). However, oxyanion metals, which include As, Se, and hexavalent $\mathrm{Cr}$, have a higher retention capacity with a $\mathrm{pH}$ of less than 7 compared with soil with a $\mathrm{pH}$ greater than 7 (Lindsay, 1979; Neal et al., 1987). Through the interaction of these factors, $\mathrm{Pb}, \mathrm{Cu}$, and $\mathrm{Ag}$ demonstrate the highest capacity for retention in soil, respectively. Conversely, $\mathrm{As}, \mathrm{Cr}$, and $\mathrm{Hg}$ are mobile if concentrations are high enough and favorable soil conditions are present (McLean and Bledsoe, 1992).

\section{MATERIALS AND METHODS}

The data used in this study were derived primarily from project files compiled by the Michigan Department of Environmental Quality (MDEQ), which oversees the investigation and cleanup of hazardous waste sites in Michigan. These data were supplemented by files generated by Clayton Group Services, a national environmental consulting firm located in Novi, Michigan. Files from more than 3000 known or suspected sites of environmental contamination were reviewed at the MDEQ southeastern Michigan district headquarters in Livonia, Michigan. Although soil samples were analyzed for heavy metals at more than 200 of these sites, fewer than 10 properties were actually sampled specifically for metals. The majority of the sites were sampled for the presence of volatile organic compounds (VOCs), including unleaded gasoline and chlorinated hydrocarbons, and were not initially suspected of having metal contamination. Most sites, however, are typically analyzed for metals as a result of regulatory or real estate due diligence requirements. The methodology used in this study to characterize urban metal concentrations in the soil relied on samples collected over a period of 10 years. This feature of the study helped average the variability of metal concentrations caused by the constantly changing near-surface urban soils versus the more stable subsurface soils.

All sites were carefully screened to eliminate obvious data bias. Specific sites excluded from the study included those with restricted access (e.g., a Cu-fabricating facility) and industrial properties with extremely high concentrations of a particular metal (e.g., a Pb smelter, a chrome-plating operation, and a gun range). Three sites were eliminated because the nearsurface soil was considered fill material of an unknown age and origin. This screening resulted in a final dataset of 3786 soil samples analyzed for heavy metals at 171 sites. Each of these sites was then classified with respect to land use and designated as residential, commercial, or industrial. The metals evaluated for this study included $\mathrm{Sb}, \mathrm{As}, \mathrm{Ba}, \mathrm{Be}, \mathrm{Cd}, \mathrm{Cr}$, $\mathrm{Cu}, \mathrm{Pb}, \mathrm{Hg}, \mathrm{Ni}, \mathrm{Se}, \mathrm{Ag}, \mathrm{Tl}$, and $\mathrm{Zn}$. Figure 1 is a map of the Rouge River watershed in southeastern Michigan, which shows the location of the 171 sites where samples were collected from the three land use categories. Table 1 shows the total number of sites that were classified as residential, commercial, or industrial and the number of samples collected from each of the soil units. The total number of sites located on the various soil units exceeds 171 because some sites were located on more than one soil unit and because samples collected from soil borings may have come from deeper soils, which were texturally distinct from the surface soil. Table 1 also indicates the percentage of sites in each land use and soil unit category.

To be consistent with previous work, all results reported 

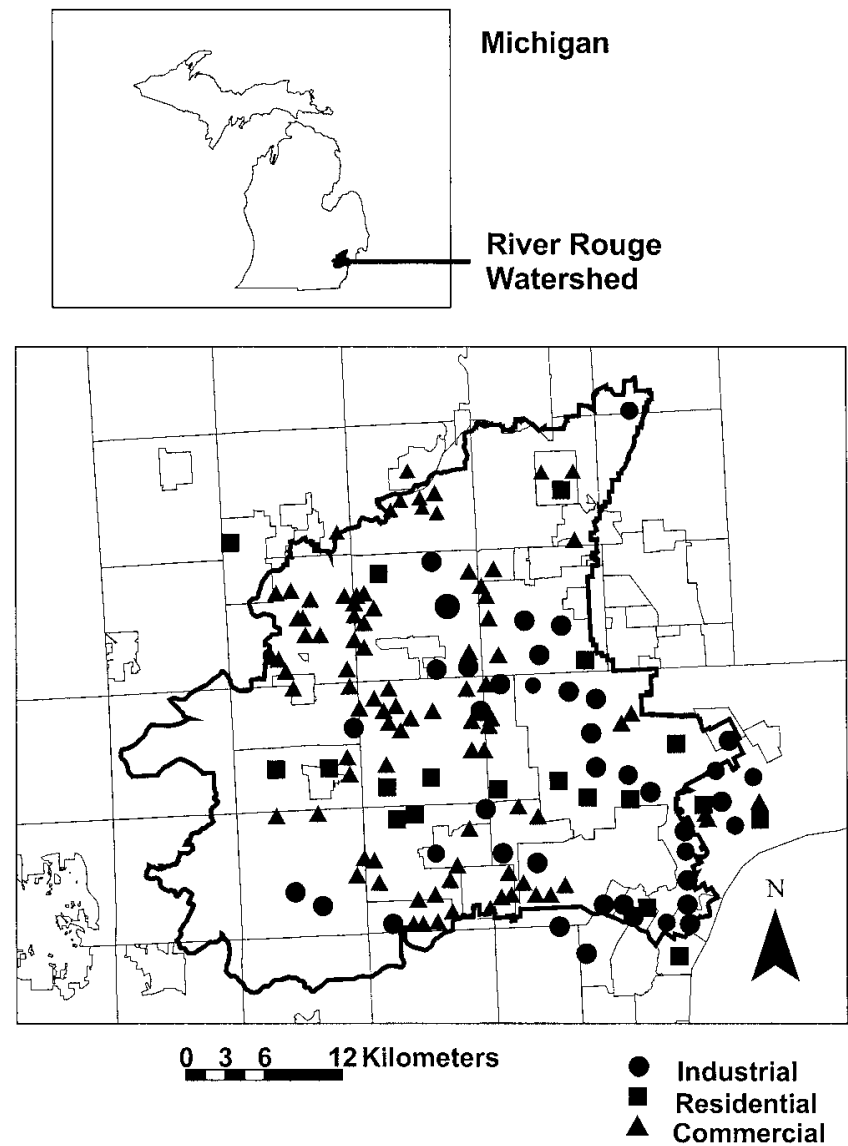

Fig. 1. Map showing the location of the land use sampling sites within the Rouge River watershed.

in this study were total recoverable levels of metals. Each metal analysis selected for inclusion in this study followed identical laboratory quality control procedures established by the MDEQ and mandated by the State of Michigan under Public Act 451, Part 201. The near-surface samples were collected from the upper $0.5 \mathrm{~m}$ of the surficial soil in the vicinity of the site being investigated. Soil collection standards typically require the collection of a soil sample at the base of the soil's A horizon using a stainless steel hand trowel or manual drive sampler. Subsurface samples were collected at depths ranging from 0.5 to $20 \mathrm{~m}$ typically during the installation of ground water monitoring wells or soil borings used to determine the areal and vertical extent of contamination during a site investigation. Soil samples were generally collected using a 0.6- or
Table 2. Metal analytical methods.

\begin{tabular}{lc}
\hline Metal & USEPA method $\dagger$ \\
\hline Arsenic & 7061 \\
Barium & 6010 \\
Cadmium & 6010 \\
Chromium & 6010 \\
Copper & 6010 \\
Lead & 6010 \\
Mercury & $\mathbf{7 4 7 0}$ \\
Nickel & 6010 \\
Selenium & $\mathbf{7 7 4 0}$ \\
Silver & $\mathbf{6 0 1 0}$ \\
Zinc & $\mathbf{6 0 1 0}$ \\
\hline
\end{tabular}

$\dagger$ USEPA (1983).

1.2-m-long steel sampler that was hydraulically pushed into the ground using a device called a Geoprobe (Geoprobe Systems, Salina, KS), or by a steel split-spoon sampler, which was pounded into the ground at various depths using a truckmounted drill rig equipped with hollow-stem augers. Subsurface soil samples would have limited exposure to automobile emissions and road runoff and should therefore have less of an anthropogenic signature.

The samples were analyzed using USEPA 6000 or 7000 series methods (USEPA, 1983) and followed all USEPA protocol (SW 846 test methods). Specific analytical methodologies for each metal are presented in Table 2. Descriptive statistics (percent, mean, range, standard deviation, and coefficient of variation) and Bartlett's test $(B)$ were used to characterize the dominant trends within the data. The Welch one-way analysis of variance (ANOVA) and Welch's $t$ test were used to test the differences between the metal concentrations in the near and shallow subsurface zones and the different soil units and land uses. All statistical tests were performed at the 0.05 level of significance.

\section{Soil Classification}

The MDNR study (Michigan Department of Natural Resources, 1991) evaluated the near-surface metal concentrations for all areas in the state. The MDNR divided the state into four regions and subdivided each sample by soil type (topsoil, sand, silt, clay, and swamp-peat). Each of the four regions corresponded to different ice sheets or lobes that occupied the region during the Pleistocene Epoch and included (i) Erie Lobe, which included the Detroit Metropolitan area; (ii) Saginaw Lobe; (iii) Michigan Lobe; and (iv) West Upper Peninsula Lobe. Each glacial lobe had a different point of origin and traveled over different types of bedrock. Therefore, the composition of soil that has subsequently developed may be different and, in turn, have different naturally occurring

Table 1. Site and sample location by land use category and geologic unit.

\begin{tabular}{|c|c|c|c|c|}
\hline & $\begin{array}{l}\text { Number } \\
\text { of sites }\end{array}$ & $\begin{array}{l}\text { Percentage } \\
\text { of sites }\end{array}$ & $\begin{array}{l}\text { Number } \\
\text { of samples }\end{array}$ & $\begin{array}{l}\text { Percentage of } \\
\text { samples }\end{array}$ \\
\hline & & $\%$ & & $\%$ \\
\hline \multicolumn{5}{|l|}{ Land use category } \\
\hline Residential & 28 & 16.4 & 847 & 22.3 \\
\hline Commercial & 95 & 55.5 & 1634 & 43.2 \\
\hline Industrial & 48 & 28.1 & 1305 & 34.5 \\
\hline Total & 171 & 100 & 3786 & 100 \\
\hline \multicolumn{5}{|l|}{ Soil units } \\
\hline Moraine & 9 & 3.8 & 74 & 3.9 \\
\hline Outwash & 6 & 2.6 & 66 & 3.5 \\
\hline Sandy and silty clay & 64 & 27.5 & 620 & 32 \\
\hline Sand & 56 & 24 & 387 & 19.8 \\
\hline Silty clay & 18 & 7.7 & 135 & 7.0 \\
\hline Upper clay & 21 & 9 & 230 & 11.8 \\
\hline Lower clay & 59 & 25.4 & 428 & 22.1 \\
\hline Total & 233 & 100 & 1940 & 100 \\
\hline
\end{tabular}




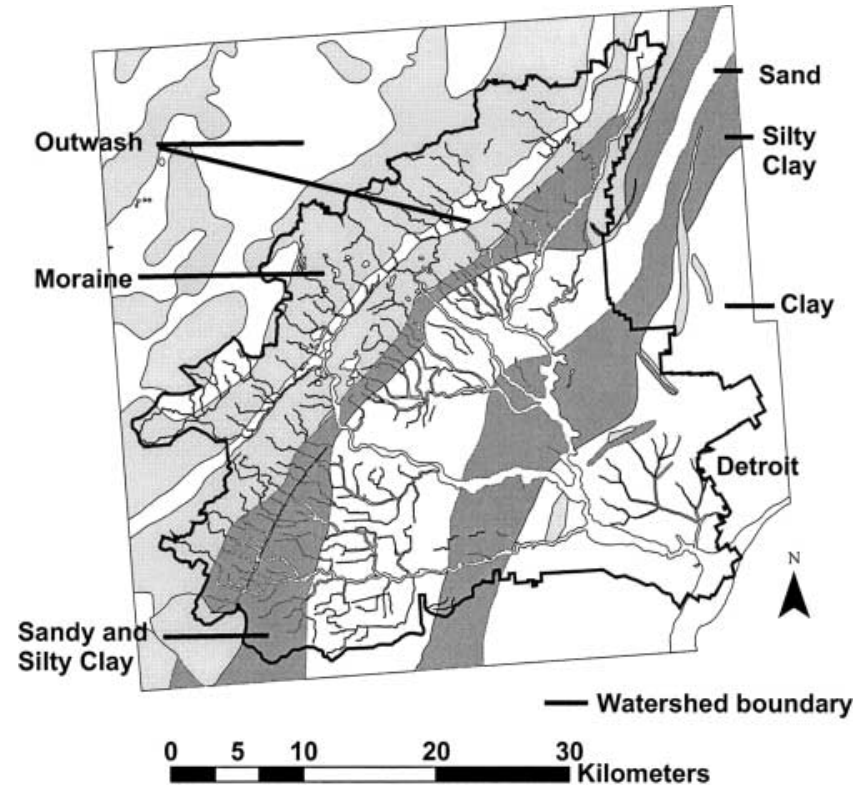

Fig. 2. Geologic map of the Rouge River watershed.

metal concentrations. It should be noted that of the 348 soil samples included in the MDNR study, only one sample was collected from topsoil from within the Erie Lobe, which includes the Detroit Metropolitan area. Thus, although the approach adopted by the MDNR to evaluate near-surface metal concentrations within similar geologic units is useful, the results of the study are of limited value to understanding background concentrations of metals in the soils of southeastern Michigan.

The surficial soils and topographic relief within the Lake Erie lobe result from several glacial advances and retreats during the recent geologic past. The resulting glacial drift has produced moraines, outwash deposits from braided streams, lake bed plains, and adjacent beach deposits. Each of these glacially derived deposits produces a texturally characteristic soil type; for example, moraines composed of glacial till are prominent in the northwestern part of the watershed and are mixtures of clay, sand, and gravel deposited by ice during glacial periods. Due to the unsorted nature of these deposits, they have locally low permeability and moderate porosity. Physical features associated with glacial moraines include outwash plains, eskers, kames, irregular drainage patterns, wetlands, and lakes. Soils generally consist of well-drained loams and sandy loams, with some areas of poorly drained sandy soils. Erosion potential is highest in this area because of the steep slopes created by the terminal moraines.

Glacial outwash deposits are found in the northwestern portion of the watershed and are present between the linear moraine deposits (Farrand, 1982, 1988; Rogers, 1997a). Outwash consists of deposits from flowing meltwater at the margins of glaciers. They are generally well-sorted and contain large amounts of sand and gravel, with minor silt and clay. Soils are medium textured and moderately well-drained and have a moderate slope. Beach and fluvial deposits formed along the western perimeter of a former glacial lake during the retreat of the Lake Erie lobe. These deposits are found in a northeast-southwest trending belt in the middle of the watershed. They tend to form very uniform, well-drained sandy soils.

Lakebeds of the old glacial lake plain are the prominent feature in the remainder (southeastern part) of the watershed (Farrand, 1982; Rogers, 1997a). These lake beds, characterized
Table 3. Range of concentration for low-occurrence metals.

\begin{tabular}{lcc}
\hline Metal & Number of samples analyzed & Range detected \\
\hline & & $\mathrm{mg} \mathrm{kg}^{-1}$ \\
Antimony & 7 & $3.7-6.1$ \\
Beryllium & 6 & $0.5-1.5$ \\
Thallium & 4 & $0.45-1.23$ \\
\hline
\end{tabular}

by low, gentle slopes, consist of clay units that may indeed be of lacustrine origin, but may also be simply a fine-grained lodgment till. They are distinguished within the Rouge River watershed by the percentage of silt and sand present and are classified as a sandy and silty clay, a sandy clay, and an upper clay. The associated soils are loams or clay loams, which are poorly drained. Beneath the lakebed plains lies a diamicton or lower clay layer also believed to be a lodgment till (J. Howard, Wayne State University, personal communication, 2003). For this study, it was assumed that samples collected from this lower clay unit, which is not exposed at the surface, except where cut by drainage, represent the natural background conditions within the watershed. Consequently, the occurrence of metals within the lower clay unit is due solely to non-anthropogenic causes. This is a reasonable assumption since the unit is typically $3 \mathrm{~m}$ below the surface and isolated from surface activities by at least $1.5 \mathrm{~m}$ of low-permeability clay (Rogers, 1997b; Murray and Rogers, 1999). Moreover, because ground water is not known to occur in this lower clay, there is negligible potential of metals migrating from anthropogenic sources via ground water pathways (Rogers, 1996; Rogers and Murray, 1997). The location and distribution of each of the above-described soil units are shown in Fig. 2.

\section{Land Use}

In addition to soils, the primary land use in the vicinity of each sampling location was taken into consideration. Significant changes in land use with time would complicate the classification, (e.g., redevelopment changing a former industrial site into one zoned for commercial use). Thus, in urban areas such as Detroit, understanding the history of land use is also important, and the changing land use patterns present significant challenges in evaluating the occurrence and distribution of metals in near-surface soil relative to land use. Although each soil sample was categorized by its current land use classification (residential, commercial, industrial), every attempt was made through the use of aerial photography (black and white, both digital and stereo pairs at a scale of 1:24 000 for years 1990, 1995, and 2000) obtained from the Southeast Michigan Council of Governments (SEMCOG) to ensure that land use had not changed substantially over the 10 -year period of this study. Obviously, significant changes in land use would tend to skew results. The inherent variability within urban soils resulting from moving, backfilling, covering, and mixing was addressed by collecting a spatially dispersed sample set (distributed across the watershed) over the period from 1992 to 2002 and using aerial photography to evaluate changes in land use at questionable sites.

Due to the differing nature of the various MDEQ investigations, not all samples were analyzed for all parameters. Within the sample set, three metals ( $\mathrm{Sb}, \mathrm{Be}$, and $\mathrm{Tl})$ were analyzed in less than $10 \%$ of the samples collected. Consequently, these metals are reported separately in Table 3 along with their respective range of detection levels. They have also been eliminated from the statistical results presented below as the sample detection limits would have disproportionately skewed the results. It is important to note that the range of detection for each of the low-occurrence metals was consistent with the range of detection reported by Shacklette and Boergnen 
Table 4. Metal distribution in the geologic units. $\dagger$

\begin{tabular}{|c|c|c|c|c|c|c|}
\hline \multirow[b]{3}{*}{ Layer } & \multicolumn{6}{|c|}{ Geologic units } \\
\hline & \multicolumn{3}{|c|}{ Westernmost geologic units } & \multicolumn{3}{|c|}{ Easternmost geologic units } \\
\hline & Moraine & Outwash & $\begin{array}{c}\text { Sandy and silty } \\
\text { clay }\end{array}$ & Sand & Silty clay & Clay \\
\hline & \multicolumn{6}{|c|}{$-\mathbf{m g ~ k g}{ }^{-1}$} \\
\hline & \multicolumn{6}{|c|}{ Arsenic } \\
\hline Surface & 1.9 (1.8), [19] & $3.6(3.4),[6]$ & $4.6(1.3),[6]$ & $5.5(6.1),[93]$ & $7.9(6.2),[138]$ & 6.5 (7.6), [221] \\
\hline Subsurface & ND & ND & $12(2.8),[15]$ & $3.1(3),[65]$ & $5.3(4.6),[142]$ & $7.2(4.2),[59]$ \\
\hline \multirow{2}{*}{ Lower clay } & ND & 4.1 (none), [1] & ND & 2.4 (1.92), [6] & $9.2(3.2),[30]$ & 5.8 (2.1), [63] \\
\hline & \multicolumn{6}{|c|}{$\underline{\text { Barium }}$} \\
\hline Surface & $31(59),[19]$ & $36(53),[6]$ & 205 (290), [6] & $80(61),[93]$ & $122(226),[90]$ & 121 (226), [126] \\
\hline Subsurface & ND & ND & $58(26),[12]$ & $20(19),[61]$ & $66(3.7),[249]$ & $61(20),[56]$ \\
\hline \multirow[t]{2}{*}{ Lower clay } & ND & 64 (none), [1] & ND & $22.5(8.9),[10]$ & $73.8(5.8),[31]$ & $51(14.8),[63]$ \\
\hline & \multicolumn{6}{|c|}{ Cadmium } \\
\hline Surface & $0.38(0.59),[25]$ & $0.14(0.12),[6]$ & $0.94(1.36),[10]$ & 0.9 (9.65), [127] & 3.5 (34.2), [184] & 3.9 (0.59), [25] \\
\hline Subsurface & ND & ND & $0.5(0.5),[71]$ & $0.4(0.53),[98]$ & $1.0(3.7),[249]$ & 0.94 (1.32), [76] \\
\hline \multirow[t]{2}{*}{ Lower clay } & ND & 0.18 (none), [1] & $0.57(0.11),[49]$ & $0.2(0.14),[12]$ & $0.28(18.5),[124]$ & $0.50(0.9),[58]$ \\
\hline & \multicolumn{6}{|c|}{ Chromium } \\
\hline Surface & $6.5(6.8),[25]$ & 12 (8.6), [6] & 17 (17.0), [33] & 30.5 (70), [109] & 63 (298), [147] & $52.5(252),[226]$ \\
\hline Subsurface & ND & ND & $9.8(6.2),[72]$ & 11 (14.6), [107] & $21(26),[252]$ & 49 (47.6), [61] \\
\hline \multirow[t]{2}{*}{ Lower clay } & ND & 13 (none), [1] & $6.6(1.1),[23]$ & $9.7(6.1),[12]$ & $14(0.24),[93]$ & $14.5(6.1),[63]$ \\
\hline & \multicolumn{6}{|c|}{ Copper } \\
\hline Surface & $7.5(9.6),[19]$ & $16(4.0),[4]$ & 31 (13), [6] & $61(98),[103]$ & 85 (234), [143] & $70(236),[389]$ \\
\hline Subsurface & ND & ND & 18 (3.8), [12] & 10 (16), [73] & $24(41),[155]$ & $37(26),[78]$ \\
\hline \multirow[t]{2}{*}{ Lower clay } & ND & 18 (none), [1] & $6.6(1.1),[23]$ & $9.8(5.96),[6]$ & $20(3.9),[28]$ & 19.5 (4.74), [63] \\
\hline & \multicolumn{6}{|c|}{ Lead } \\
\hline Surface & 8.8 (13), [37] & 8.0 (4.7), [16] & $90(15),[13]$ & $65(78),[129]$ & 108 (335), [337] & $162(405),[1343]$ \\
\hline Subsurface & ND & ND & 22 (104), [145] & 6.3 (11.5), [446] & $30(68),[518]$ & $58(142),[202]$ \\
\hline \multirow[t]{2}{*}{ Lower clay } & 4.1 (none), [1] & $7.9(2.1),[3]$ & $11.3(10.1),[75]$ & 4.1 (none), $[1]$ & $7.9(2.1),[3]$ & $11.3(10.1),[75]$ \\
\hline & \multicolumn{6}{|c|}{ Mercury } \\
\hline Surface & 0.07 (0.012), [11] & $0.06(0.04),[6]$ & $0.2(0.05),[5]$ & $0.1(0.25),[92]$ & $0.17(0.27),[109]$ & $0.27(0.41),[122]$ \\
\hline Subsurface & ND & ND & $0.06(0.025),[10]$ & $0.06(0.11),[54]$ & $0.98(0.08),[102]$ & $0.07(0.09),[60]$ \\
\hline \multirow[t]{2}{*}{ Lower clay } & ND & 0.1 (none), [1] & ND & $0.015(0.002),[4]$ & $0.1(0.04),[26]$ & $0.09(0.04),[63]$ \\
\hline & \multicolumn{6}{|c|}{ Nickel } \\
\hline Surface & $0.09(0.59),[25]$ & $0.14(0.12),[6]$ & $0.94(1.36),[10]$ & $17.5(260),[54]$ & 28 (83), [100] & $51(150),[138]$ \\
\hline Subsurface & ND & ND & 11.5 (7.85), [26] & $8.4(16),[49]$ & $22.6(10),[19]$ & $20(2.5),[3]$ \\
\hline \multirow[t]{2}{*}{ Lower clay } & ND & ND & ND & ND & ND & $0.09(2.2),[8]$ \\
\hline & \multicolumn{6}{|c|}{ Selenium } \\
\hline Surface & $0.37(0.125),[11]$ & $0.06(0.22),[8]$ & $0.33(0.45),[5]$ & $0.4(0.35),[92]$ & 0.96 (1.46), [99] & 1.85 (2.9), [119] \\
\hline Subsurface & ND & ND & $0.12(0.05),[8]$ & $0.5(0.5),[56]$ & $0.75(0.69),[98]$ & $1.1(0.8),[59]$ \\
\hline Lower clay & ND & 0.05 (none), [1] & ND & $0.6(0.2),[4]$ & $0.23(0.19),[24]$ & $0.93(0.93),[58]$ \\
\hline & & & & & & \\
\hline Surface & $0.37(0.125),[11]$ & 0.4 (0.13), [8] & $2.3(0.7),[5]$ & $0.5(0.42),[91]$ & $1.23(2.6),[104]$ & 1.72 (4.1), [101] \\
\hline Surface & ND & ND & $0.3(0.5),[8]$ & $1.0(3),[56]$ & $2.65(0.18),[102]$ & $0.41(0.56),[35]$ \\
\hline Lower clay & ND & 0.5 (none), [1] & ND & $0.38(0.36),[4]$ & $1.2(1.7),[26]$ & $0.54(1.85),[41]$ \\
\hline & & & & & & \\
\hline Surface & $49(76),[18]$ & 49 (16), [4] & 138 (112), [6] & $160(96),[102]$ & $221(416),[141]$ & 251 (439), [251] \\
\hline Subsurface & ND & ND & 42 (79), [15] & $26(40),[77]$ & 77 (115), [147] & $84.5(85),[78]$ \\
\hline Lower clay & ND & 42 (none), [1] & 31.7 (4.52), [2] & $31(22),[8]$ & 56 (14.5), [32] & $36.4(6.4),[62]$ \\
\hline
\end{tabular}

$\dagger$ Concentrations are derived from Michigan Department of Environmental Quality (MDEQ) files. Values in parentheses are standard deviations, while those in brackets are numbers of samples.

$\$$ ND, no data.

(1984). A review of the occurrence data suggests that all of these metals are probably the result of anthropogenic sources rather than from natural occurrence. The analytical results for the 11 remaining metals are presented in Tables 4 and 5. Table 4 indicates each metal's horizontal (west to east distribution across the six soil units within the watershed) and vertical (surface, subsurface, and lower clay) distribution across the watershed. Table 5 reports each metal's mean concentration in both surface and subsurface soils across each of the three land use categories.

\section{RESULTS AND DISCUSSION}

A few trends are apparent from this analysis: (i) surface concentrations are generally greater than subsur- face and (ii) concentrations generally increase in a west to east direction across the watershed. This latter trend is commensurate with a west to east increase in urbanization and industrialization. The moraine unit shows consistently lower levels of metals than any of the other soil units, and has mean concentrations of metals statistically similar to that found in the lower clay layer, which is assumed to contain naturally occurring metal concentrations. Although the moraine has locally high permeability, it generally contains substantially more clay than either the outwash or the sand units. The low concentration of metals found in this unit is thus attributed to fewer anthropogenic sources in the western, more rural 
Table 5. Mean concentration of metals in soil relative to land use. $\dagger$

\begin{tabular}{|c|c|c|c|c|c|c|c|c|c|c|c|c|c|c|c|c|c|c|}
\hline & \multicolumn{9}{|c|}{ Surface soil } & \multicolumn{9}{|c|}{ Subsurface soil } \\
\hline & \multicolumn{3}{|c|}{ Commercial } & \multicolumn{3}{|c|}{ Residential } & \multicolumn{3}{|c|}{ Industrial } & \multicolumn{3}{|c|}{ Commerical } & \multicolumn{3}{|c|}{ Residential } & \multicolumn{3}{|c|}{ Industrial } \\
\hline & $N$ & $X$ & SD & $N$ & $X$ & SD & $N$ & $X$ & SD & $N$ & $\boldsymbol{X}$ & SD & $N$ & $X$ & SD & $N$ & $x$ & SD \\
\hline & \multicolumn{3}{|c|}{ — $\mathrm{mg} \mathrm{kg}^{-1}$ - } & & \multicolumn{2}{|c|}{$-\mathrm{mg} \mathrm{kg}^{-1}-$} & \multicolumn{3}{|c|}{ - $\mathbf{m g ~ k g ^ { - 1 } -}$} & & \multicolumn{2}{|c|}{ - $\mathbf{m g ~ k g}^{-1}-$} & \multicolumn{3}{|c|}{$-\mathbf{m g ~ k g} \mathbf{k g}^{-1}-$} & & \multicolumn{2}{|c|}{ - $\mathbf{m g} \mathbf{k g}^{-1}-$} \\
\hline As & 205 & 5.1 & 5.5 & 77 & 6.3 & 4 & 201 & 7 & 9 & 95 & 5.6 & 4.0 & 78 & 2.3 & 4.2 & 108 & 7.1 & 4.2 \\
\hline Ba & 151 & 69 & 66 & 71 & 128 & 135 & 118 & 148 & 222 & 90 & 55 & 25 & 70 & 61 & 37 & 82 & 76 & 24 \\
\hline Cd & 234 & 2.2 & 1.5 & 80 & 1.1 & 1.1 & 151 & 4.5 & 13 & 306 & 0.5 & 1.5 & 86 & 0.4 & 0.5 & 102 & 1.9 & 2.5 \\
\hline $\mathbf{C r}$ & 282 & 27 & 83 & 67 & 31 & 52 & 197 & 55 & 159 & 292 & 11.6 & 14 & 96 & 25.4 & 38 & 104 & 27 & 35 \\
\hline $\mathbf{C u}$ & 205 & 32 & 60 & 82 & 30 & 39 & 377 & 113 & 269 & 98 & 20 & 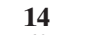 & 94 & 26 & 57 & 126 & 14 & 17 \\
\hline $\mathbf{P b}$ & 418 & 93 & 300 & 535 & 160 & 250 & 893 & 150 & 380 & 906 & 20 & 60 & 220 & 34 & 77 & 185 & 39 & 72 \\
\hline $\mathbf{H g}$ & 167 & 0.2 & 0.24 & 58 & 0.08 & 0.07 & 120 & 0.2 & 0.3 & 88 & 0.05 & 0.01 & 53 & 0.1 & 0.8 & 85 & 0.08 & 0.05 \\
\hline $\mathrm{Ni}$ & 151 & 16 & 9.8 & 35 & 24 & 29 & 132 & 58 & 150 & 3 & 36 & 3 & 18 & 11 & 7 & 38 & 14.5 & 24 \\
\hline Se & 164 & 0.6 & 0.3 & 57 & 0.8 & 0.8 & 113 & 1.9 & 2.2 & 90 & 0.8 & 0.6 & 53 & 0.35 & 0.2 & 82 & 0.9 & 0.9 \\
\hline $\mathbf{A g}$ & 152 & 0.5 & 0.2 & 54 & 0.8 & 0.5 & 114 & 2.3 & 2.2 & 67 & 0.6 & 0.4 & 48 & 0.5 & 1.1 & 72 & 2.2 & 4 \\
\hline $\mathbf{Z n}_{\mathbf{n}}$ & 202 & 130 & 310 & 81 & 120 & 124 & 239 & 257 & 534 & 94 & 67 & 137 & 98 & 66 & 80 & 115 & 60 & 60 \\
\hline
\end{tabular}

$\dagger N$, number of samples; $X$, mean concentration; SD, standard deviation.

part of the watershed. More interesting, however, is the relatively high concentration of metals found in the sand unit. The sand unit varies in thickness from less than $1 \mathrm{~m}$ to more than $10 \mathrm{~m}$ and is highly permeable with a hydraulic conductivity ranging from $10^{-4}$ to $10^{-1} \mathrm{~cm} \mathrm{~s}^{-1}$ (Rogers and Murray, 1997). Yet, the sand unit contains statistically higher concentrations of metals than either the moraine or outwash units, which are both exposed at the surface westward of the sand (Fig. 3). The explanation for this apparent paradox is the location of the sand within the watershed. The sand is located in the center of the watershed along the urban fringe (Fig. 2). This area has undergone rapid urbanization and industrialization over the past 20 years and represents the transition between the rural western and the more heavily industrialized eastern part of the watershed. Contamination derived from spills, leaking underground or above tanks, can quickly pass through the vadose zone within the sand to reach the water table, typically at a depth of no more than $3 \mathrm{~m}$ below the ground surface. Consequently, this part of the watershed has the highest incidence of ground water contamination (Murray and Rogers, 1999; Kaufman et al., 2003), and the sand unit, despite its lack of clay and organic material contains a higher concentration of the metals most often associated with industry ( $\mathrm{As}, \mathrm{Ba}, \mathrm{Cd}, \mathrm{Cr}, \mathrm{Cu}, \mathrm{Ni}$, and $\mathrm{Se}$ ) than even the sandy silty clay unit that is located immediately to the west. The pivotal position and characteristics of the sand unit are underscored by metal concentrations that are typically $50 \%$ less than the metal concentrations found in the two easternmost clay-rich units.

The silty clay unit, which is exposed at the surface immediately to the east of the sand unit, contains the highest As concentrations of all the soil units with its highest concentrations found in both surface and subsurface soils in industrial areas. Arsenic concentrations were expected to be uniformly high across the entire watershed, as a function of either the weathering of natural As-bearing minerals associated with the underlying Marshall Sandstone, or from the atmospheric deposition associated with coal fired power plants. This was not the case. In fact, relatively modest levels of As were present in both surface and subsurface soils across all three land-use categories and all soils with the exception of the silty clay. The distribution of As within the watershed may thus result from localized industrial sources of As and conditions that serve to increase its mobility. These conditions include an adequately high concentration, a $\mathrm{pH}$ greater than 7 , and the oxidation state of the As. For example, $\mathrm{As}(\mathrm{V})$ is the dominant form of As under aerobic conditions found in the nearsurface soils. In this oxidized state As will strongly bind with soil and sediment, particularly in clay-rich soils. However, in an anaerobic environment, conditions associated with the subsurface clay-rich soils, As generally forms insoluble and nonmobile sulfides.

The silty clay unit also contains substantially higher levels of $\mathrm{Ba}, \mathrm{Cd}, \mathrm{Pb}$, and $\mathrm{Zn}$ than any of the other

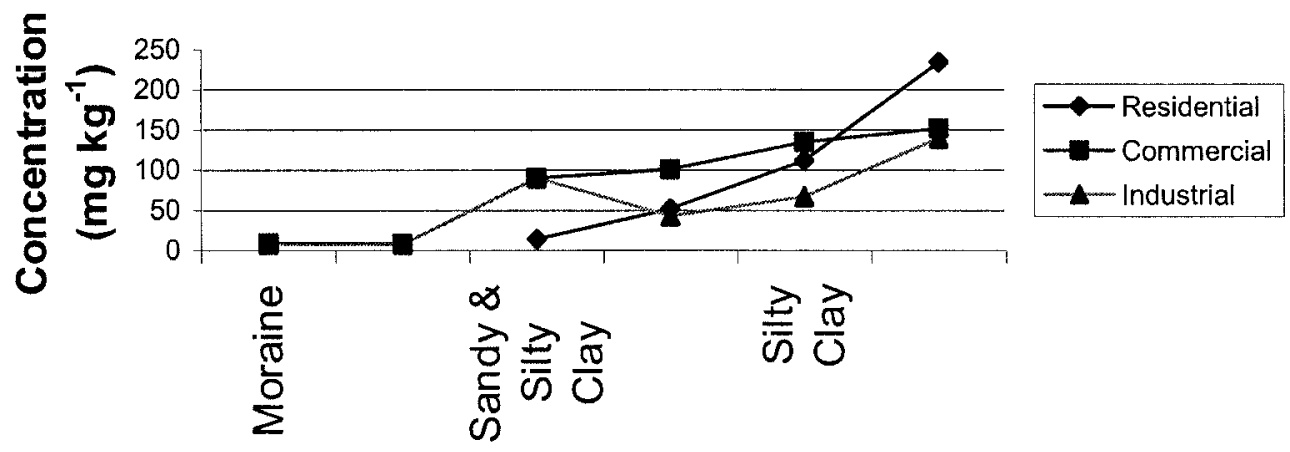

West to East Distribution of Soil Units

Fig. 3. West to east concentration of $\mathrm{Pb}$ in surface soil versus land use. 
soils units. Because the silty clay is located in the more industrialized part of the watershed, the higher concentration of these metals suggests anthropogenic sources. This premise is supported by the data presented in Table 5, which indicate almost uniformly higher metal concentrations in industrial land uses in both surface and subsurface soils. Two notable exceptions were the high $\mathrm{Pb}$ and $\mathrm{Hg}$ levels present in residential areas in the surface and shallow subsurface soils, respectively. Lead in the surface soils in residential areas was present at levels 16 times that found in the lower clay layer. The high $\mathrm{Pb}$ levels are probably due to deposition of $\mathrm{Pb}$ dust from sources such as $\mathrm{Pb}$-based paints in older residences common in urban areas and the former use of leaded gasoline (Mielke et al., 1983, 1984; Mielke, 1999). Subsurface $\mathrm{Pb}$ concentrations in residential areas are also relatively high, with mean values at more than twice the background levels found in the lower clay layer. Mean values of surface $\mathrm{Pb}$ in industrial areas (15.5 times background) are nearly as high as in residential areas (16 times background) with several industrial sites (and surrounding neighborhoods) exhibiting $\mathrm{Pb}$ concentrations hundreds of times the background concentration. In addition, subsurface $\mathrm{Pb}$ in industrial areas was nearly five times higher than the background level (Fig. 3), underscoring the effect of industry's role in contributing to soil $\mathrm{Pb}$ contamination.

Mercury was present in the near-surface soils in commercial areas at levels four times the background level of $0.09 \mathrm{mg} \mathrm{kg}^{-1}$ present in the lower clay unit. Throughout most of the subsurface, $\mathrm{Hg}$ concentrations are equivalent to background levels, while $\mathrm{Hg}$ concentrations at commercial and industrial sites are more than twice the background levels. The high incidence of $\mathrm{Hg}$ at industrial sites is probably related to the production of chlorine, caustic soda, and hydrogen. It may also be related to former automotive paint industries or the production of electrical equipment (Jaagumagi, 1993). The high incidence of $\mathrm{Hg}$ at commercial sites is more problematic and may reflect changing land use in an urban area with an industrial base that is more than 100 years old.

Concentrations of $\mathrm{Cu}$ and $\mathrm{Zn}$ at the surface were significantly lower at residential and commercial properties compared with industrial properties. This suggests that the primary sources of $\mathrm{Cu}$ and $\mathrm{Zn}$ were industry related. In addition, concentrations of many other heavy metals, such as $\mathrm{Cd}, \mathrm{Cr}, \mathrm{Ni}, \mathrm{Se}$, and $\mathrm{Ag}$, were also detected in surface soil at industrial properties at higher concentrations than commercial and residential properties. This again suggests that the elevated concentrations of these metals may have an anthropogenic source, presumably industrial sites. On the other hand, concentrations of $\mathrm{Ba}, \mathrm{Hg}$, and As did not vary significantly between the land use categories, implying that these metals do not have a significant anthropogenic source.

Concentrations of heavy metals in the lower clay unit differ only slightly from the heavy metal concentrations observed in previous Michigan studies. In fact, most metals (As, $\mathrm{Ba}, \mathrm{Cd}, \mathrm{Cr}, \mathrm{Pb}, \mathrm{Hg}, \mathrm{Ni}, \mathrm{Ag}$, and $\mathrm{Zn}$ ) were present at mean concentrations slightly less than the previous Michigan studies. Only $\mathrm{Cu}$ and Se were present at mean concentrations greater than those of previous studies; however, these elevated concentrations would not be considered statistically significant. These results support our contention that metal concentrations in the lower clay unit within the Rouge River watershed can be reasonably interpreted to represent naturally occurring concentrations of heavy metals and confirm their use as background heavy metal concentrations for this study.

Comparing the results of the land use data to background, it was expected that the metals would be highest for industrial and lowest for residential areas. In surface soils, industrial land use was indeed the highest for each metal, with the modest exception of $\mathrm{Pb}$ as discussed above. However, instead of residential having the lowest concentration, the commercial category had the lowest metal concentrations for 7 of the 11 metals included in this analysis. The exceptions were $\mathrm{Cd}, \mathrm{Cu}, \mathrm{Hg}$, and $\mathrm{Zn}$. In subsurface soils these four metals (plus $\mathrm{Ni}$ ) continued to be present at higher concentrations than subsurface soils from residential areas.

\section{Statistical Results}

The metal data were compiled into a set of squared cumulative frequency curves that compare the range of analytical results to their frequency. An example frequency curve for $\mathrm{Pb}$ concentrations in residential areas versus $\mathrm{Pb}$ concentrations found in the lower clay unit is shown in Fig. 4. These curves indicate that the analytical results are positively skewed and log normal for all metals. Due to the log normal distribution, the geometric data were chosen as the most representative of geochemical abundance. For example, Table 6 indicates the number of samples, geometric mean, median, range (minimum and maximum), standard deviation, and coefficient of variation (standard deviation divided by the mean) calculated for each soil and land use category for surface $\mathrm{Pb}$.

Descriptive statistics (percent, mean range, standard deviation, and coefficient of variation) were used to characterize the dominant trends within the data. Bartlett's test $(B)$, which produces an $F$ ratio, was used

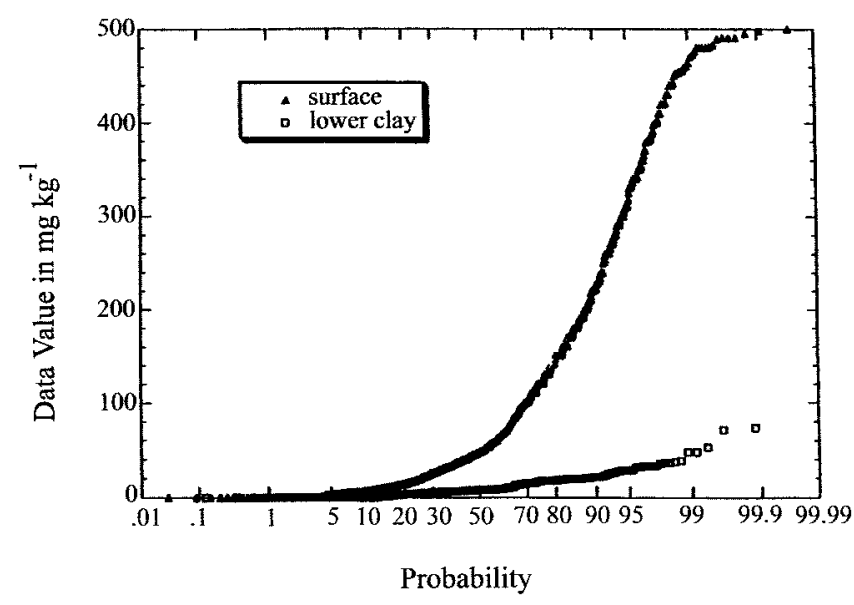

Fig. 4. Cumulative frequency curve for $\mathrm{Pb}$ in surface soil versus the lower clay unit. 
Table 6. Lead in surface soils. $\dagger$

\begin{tabular}{|c|c|c|c|c|c|c|c|}
\hline & Minimum & Maximum & $\begin{array}{l}\text { Geometric } \\
\text { mean }\end{array}$ & Median & $\begin{array}{l}\text { Standard } \\
\text { deviation }\end{array}$ & $\begin{array}{l}\text { Number of } \\
\text { samples }\end{array}$ & $\begin{array}{c}\text { Coefficient of } \\
\text { variation }\end{array}$ \\
\hline & & & $\mathbf{m g ~ k g}{ }^{-1}$ & & - & & \\
\hline \multicolumn{8}{|l|}{ Soil unit } \\
\hline Sandy clay & 0.0027 & 61.6 & 9.51 & 6.4 & 10.31 & 128 & 1.08 \\
\hline Sand & 0.003 & 58 & 7.49 & 4 & 8.88 & 367 & 1.17 \\
\hline Sandy and silty clay & 0.0049 & 307 & 34.04 & 9 & 63.63 & 560 & 1.86 \\
\hline Upper clay & 0.003 & 180 & 22.17 & 11 & 31.99 & 206 & 1.44 \\
\hline Moraine & 0.003 & 132 & 16.27 & 6.3 & 26.47 & 399 & 1.62 \\
\hline Outwash & 1.0 & 19 & 7.21 & 7 & 3.54 & 65 & 0.48 \\
\hline Lower clay & 0.003 & 73 & 10.55 & 7.4 & 9.92 & 73 & 0.94 \\
\hline \multicolumn{8}{|l|}{ Land use category } \\
\hline Commercial & 0.003 & 7460 & 92.74 & 15.4 & 444.96 & 321 & 4.79 \\
\hline Residential & 0.006 & 2890 & 160.02 & 69.5 & 275.45 & 540 & 1.72 \\
\hline Industrial & 0.004 & 6190 & 150.83 & 55 & 385.16 & 901 & 2.55 \\
\hline
\end{tabular}

$\dagger$ Data derived from Michigan Department of Environmental Quality (MDEQ) files.

to confirm the unequal variances between the metal concentrations in the different soil groups and land uses. The Welch ANOVA and Welch $t$ tests were used to test the differences between specific metal concentrations in the near-surface and shallow subsurface zones, and the different soil units and land uses. All statistical tests were performed at the 0.05 level of significance. For example, in surface soil mean $\mathrm{Pb}$ concentrations differ significantly across the six different soil groups $(B=$ 132.7, $p<0.0001$; Welch ANOVA $F=64.3, p<0.0001$ ), gradually increasing in concentration in a west to east direction commensurate with an increase in anthropogenic sources of $\mathrm{Pb}$, including a higher incidence of older homes containing $\mathrm{Pb}$-based paint, a higher occurrence of residual $\mathrm{Pb}$ in the soil derived from the former use of leaded gasoline, and a higher incidence of industrial sources. The only deviation from this trend was a lower level of $\mathrm{Pb}$ in the sand unit than in the sandy and silty clay unit located to the west of the sand. This discrepancy, however, can be explained by the lack of adsorptive characteristics relative to the sandy and silty clay. As discussed above, the sand unit contains virtually no clay yet still has mean surface concentrations of $\mathrm{Pb}$ that are nearly eight times that found in the moraine and outwash units that contain on average $20 \%$ or more clay. Mean $\mathrm{Pb}$ concentrations at the surface were also significantly different across all land uses $(B=38.4, p<$ 0.0001 ; Welch ANOVA $F=5.9, p<0.01$ ), with mean $\mathrm{Pb}$ levels in surface soil derived from residential areas approximately 16 times that of the mean $\mathrm{Pb}$ concentrations found in the lower clay unit. Additionally, mean $\mathrm{Pb}$ concentrations at the surface were significantly different within any one land use category (e.g., commercial land use) when evaluated across all soil units $(B=162.3$, $p<0.0001$; Welch ANOVA $F=10.6, p<0.0001$ ), suggesting that the west to east trend is independent of land use and is thus probably a function of an overall increase in urbanization and industrialization.

In the shallow subsurface soils mean $\mathrm{Pb}$ concentrations were also significantly different across all soil units $(B=391.0 ; p<0.0001$; Welch ANOVA $F=22.0, p<$ $0.0001)$, with mean $\mathrm{Pb}$ concentrations in the upper clay, which is exposed at the surface in the easternmost part of the watershed, including the City of Detroit, nearly twice the level of the mean $\mathrm{Pb}$ concentration found in the adjacent silty clay unit and more than five times the background concentration of $\mathrm{Pb}$ found in the lower clay unit (Table 4). Interestingly, there is no statistically significant difference in the mean concentrations of $\mathrm{Pb}$ within the subsurface between commercial and residential land uses $(B=24.2, p<0.0001$; Welch ANOVA $F=2.0, p=0.06$ [not significant]), despite the high surface concentrations of $\mathrm{Pb}$ in residential areas. The mean $\mathrm{Pb}$ concentrations at industrial sites in shallow subsurface soils were statistically different $(B=95.0$, $p<0.0001$; Welch ANOVA $F=20.0, p<0.0001)$ from the mean $\mathrm{Pb}$ values in subsurface soil at either commercial or residential sites and were still three times the mean background concentration of $\mathrm{Pb}$ found in the lower clay unit.

\section{Previous Investigations}

The Kesler-Arnold and MDNR studies evaluated naturally occurring metal concentrations at different rural locations in southeastern Michigan. The results of both studies were consistent with each other and were similar to the metal concentrations found in the lower clay of the Rouge River watershed. Both studies also found similar relationships between metal concentrations and the textural characteristics of the soil (i.e., metal concentrations were lowest in sandy soils and highest in clayrich soils for each of the metals evaluated). The results of the Ohio study conducted by Cox and Colvin (1995) study compare most closely to the clay-rich soils of southeastern Michigan.

The USGS study of Shacklette and Boerngen (1984) indicated slightly higher concentrations of $\mathrm{As}, \mathrm{Cr}, \mathrm{Cu}$, $\mathrm{Pb}, \mathrm{Hg}, \mathrm{Se}$, and $\mathrm{Zn}$ than the rural Michigan and Ohio studies, but still lower levels of these metals than what was found in the surface soils of the current study. The one exception was $\mathrm{Ba}$, which was found at concentrations from 5 to 10 times greater than the current study. The Shacklette and Boerngen (1984) study did not include the metals $\mathrm{Cd}$ or $\mathrm{Ag}$.

In a study of heavy metal concentrations in England and Wales conducted by Thornton (1991), 5800 topsoil (0-15 cm deep) samples were collected at 5-km intervals on a square grid as part of a national inventory of soils. Unlike the studies conducted by the USGS in the United States, these studies included urban and rural areas. The results of the urban component of this study indicated 
higher concentrations of $\mathrm{Pb}, \mathrm{Cr}$, and $\mathrm{Zn}$ compared with results of the USGS studies, but similar to the results of the surface clay-rich soils of the Rouge River watershed. Copper and $\mathrm{Ni}$ concentrations were comparable with studies by the USGS. Arsenic, $\mathrm{Ba}, \mathrm{Hg}$, and $\mathrm{Ag}$ were not included in the Thornton (1991) study.

The results from our investigation most closely resemble the work recently completed in Rhode Island by Alkhatib and O'Connor (1998). Southeastern Michigan soils however, differ distinctly from the Rhode Island soils by having much higher concentrations of As and $\mathrm{Pb}$, but significantly lower concentrations of $\mathrm{Be}, \mathrm{Cr}$, and $\mathrm{Cu}$. There are two likely explanations for these distinctions. The first is a difference in the geologic origin of the Rhode Island soils, which may be as variable as soils produced by the different glacial lobes in Michigan. The second possibility is that the soils in each region are affected differently by the type of industry prevalent in the urban areas, with the automobile industry, for example, dominant in southeastern Michigan.

The identification of $\mathrm{Pb}$ as the heavy metal with the most apparent anthropogenic input is probably due to (i) many different sources of $\mathrm{Pb}$ (USEPA, 1998) and (ii) $\mathrm{Pb}$ 's high capacity for retention in clay-rich soil (McLean and Bledsoe, 1992). Furthermore, the identification of $\mathrm{Pb}$ as having significant anthropogenic input into the environment is in agreement with the recent regulatory concern about the presence of $\mathrm{Pb}$ in the environment (United States Department of Health and Human Services, 1988; Florini, 1990; Environmental Defense Fund, 1994; USEPA, 1998).

The results of this study have important implications for land use planning and for future site investigations in urban areas when heavy metal contamination is suspected. First, the evaluation of human and ecological risk can be achieved by concentrating investigation efforts on heavy metals in the surface soils. The results of this study have demonstrated that heavy metal concentrations are highest at the surface and quickly decrease with increasing depth. Therefore, concentrating investigative efforts at the surface will efficiently identify the most elevated heavy metal concentrations derived from anthropogenic sources. Second, innovative regional strategies for the cleanup of sites with metal contamination need to be developed. Cost-effective remedial technologies that focus on the near-surface soil such as phytoremediation, which relies on plant root systems to reduce metal concentrations in near-surface soil, may thus be able to play a larger role in site cleanup than previously realized. Third, the identification of potential hydrologic and ecological effects of metals in the near-surface zone is essential for the protection of ground water. Since this study has identified that the occurrence of heavy metals in an urban environment is highest at the surface, the results can be integrated into evaluations of interflow, baseflow, increased leaching from acid rain, infiltration-inflow to public water supplies, runoff to surface water systems, and the potential revegetation capacity at redeveloped sites. Fourth, the mapping of glacial deposits in the Midwest can pinpoint soils particularly sensitive and prone to contamination.
Finally, future research related to metal concentrations in soils in other urban areas should consider the effect of historic land use activities and the potential human health issues and risks associated with heavy metals in the surface soils.

\section{CONCLUSIONS}

This study represents an initial effort to characterize the metal concentrations in surface and near-surface soil in an urban environment in southeastern Michigan. The results of this study have demonstrated that metal concentrations in an urban environment are greatest at the surface and typically increase in a west to east trend across the watershed commensurate with a general west to east increase in urbanization and industrial activity. Results identify $\mathrm{Pb}$ as the heavy metal with the highest surface concentration with mean levels present at more than 16 times background at residential sites and 15.5 times greater than background at industrial sites. More importantly, $\mathrm{Pb}$ concentrations have been found in surface soil at specific industrial sites and adjacent residential neighborhoods at levels hundreds of times the level that may occur naturally in the soil.

The results have also confirmed elevated concentrations of $\mathrm{Ba}, \mathrm{Cd}, \mathrm{Cr}, \mathrm{Cu}, \mathrm{Ni}$, and $\mathrm{Zn}$ in surface soils from probable anthropogenic sources, and the effects from $\mathrm{Cd}, \mathrm{Cr}, \mathrm{Cu}, \mathrm{Ni}$, and $\mathrm{Zn}$ in soil occur more frequently at industrial properties compared with commercial and residential properties.

Heavy metal concentrations beneath the surface (at depths between 0.5 and $10 \mathrm{~m}$ ), although elevated, were in general agreement with those of previous studies conducted in Michigan and other areas of the United States. Heavy metal concentrations in soils at depths greater than $10 \mathrm{~m}$ are in complete agreement with previous studies of heavy metal concentrations in rural areas of Michigan and other areas of the United States. This suggests that soils at depths greater than $10 \mathrm{~m}$ are generally only affected to a minor extent from anthropogenic heavy metal sources.

\section{ACKNOWLEDGMENTS}

The authors would like to thank the Michigan Department of Environmental Quality for their assistance and input from several individuals who made this research possible. The authors would also like to extend appreciation to Ms. Caroline Copeland and Mr. Doug McVey at Clayton Group Services for their tireless commitment and scientific expertise in assembling, evaluating, and reviewing the data.

\section{REFERENCES}

Alkhatib, E., and T. O'Connor. 1998. Background levels of priority pollutant metals in soil. Am. Environ. Lab. 10:6-9.

Cox, C.A., and G.H. Colvin. 1995. Investigation of background metal concentrations in Ohio soils. Cox-Colvin and Associates, Hillard, $\mathrm{OH}$.

Environmental Defense Fund. 1994. The global dimensions of lead poisoning. EDF, Washington, DC.

Farrand, W.R. 1982. Quaternary geology of southern (\& northern) Michigan. 1:500,000. Michigan Dep. of Nat. Resour., Geol. Survey Div., Lansing. 
Farrand, W.R. 1988. The glacial lakes around Michigan. Bull. 4. Michigan Dep. of Nat. Resour., Lansing.

Florini, K.L. 1990. Legacy of lead: America's continuing epidemic of childhood lead poisoning. Environ. Defense Fund, Washington, DC.

Harter, R.D., and R.G. Lehmann. 1983. Use of kinetics for the study of exchange reactions in soils. Soil Sci. Soc. Am. J. 47:666-669.

Holmgren, G.G.S., M.W. Meyer, R.L. Chaney, and R.B. Daniels. 1993. Cadmium, lead, zinc, copper and nickel in agricultural soils of the United States of America. J. Environ. Qual. 22:335-348.

Jaagumagi, R. 1993. Development of the Ontario Provincial Sediment Quality Guidelines for arsenic, cadmium, chromium, copper, iron, lead, manganese, mercury, nickel and zinc. Ministry of Environ. and Energy, Toronto.

Kaufman, M.M., K.S. Murray, and D.T. Rogers. 2003. Surface and subsurface geologic risk factors to ground water affecting brownfield redevelopment potential. J. Environ. Qual. 2003 32:490-499.

Kesler-Arnold, K.A., and M.O. O'Hearn. 1990. Background concentrations of metals and cyanide in lower Michigan soils. p. 123-137. In Proc. 44th Purdue Industrial Waste Conf., West Lafayette, IN. 19-23 June 1990. Lewis Publ., Chelsea, MI.

Lindsay, W.L. 1979. Chemical equilibria in soils. John Wiley \& Sons, New York.

Ma, L.Q., F. Tan, and W.G. Harris. 1997. Concentration and distribution of eleven metals in Florida soils. J. Environ. Qual. 26:769-775.

Mattigod, S.V., G. Sposito, and A.L. Page. 1981. Factors affecting the solubilities of trace metals in soils. p. 203-221. In D.E. Baker (ed.) Chemistry in the soil environment. ASA Spec. Publ. 40. ASA and SSSA, Madison, WI.

McLean, J.E., and B.E. Bledsoe. 1992. Ground water issue: Behavior of metals in soils. Technol. Innovation Office, Office of Solid Waste and Emergency Response, USEPA, Washington, DC.

Michigan Department of Environmental Quality. 1998. Natural Resources Environmental Protection Act 451 (NREPA), as amended. MDEQ, Lansing.

Michigan Department of Natural Resources. 1991. Michigan background soil survey. Waste Manage. Div., Lansing.

Mielke, H.W., J.C. Anderson, K.J. Berry, P.W. Mielke, and R.L. Chaney. 1983. Lead concentrations in inner city soils as a factor in the child lead problem. Am. J. Public Health 73:1366-1369.

Mielke, J.H. 1999. Lead in the inner cities. Am. Sci. 87:62-73.

Mielke, J.H., B. Blake, S. Burroughs, and N. Hassinger. 1984. Urban lead levels in Minneapolis: The case of the Hmong children. Environ. Res. 34:64-76.

Miller, W.P., and W.W. McFee. 1983. Distribution of cadmium, zinc, copper and lead in soils of industrial northwestern Indiana. J. Environ. Qual. 12:29-33.

Murray, K.S., D. Cauvet, M. Lybeer, and J.C. Thomas. 1999. Particle size and chemical control of heavy metals in bed sediment from the Rouge River, southeast Michigan. Environ. Sci. Technol. 33:987-992.

Murray, K.S., and D.T. Rogers. 1999. Groundwater vulnerability, brownfield redevelopment and land use planning. J. Environ. Plann. Manage. 42:801-810.

Neal, R.H., G. Sposito, K.M. Holtzclaw, and S.J. Traina. 1987. Selenite absorption on alluvial soils: I. Soil composition and $\mathrm{pH}$ effects. Soil Sci. Soc. Am. J. 51:1165-1169.

Rogers, D.T. 1996. Environmental geology of metropolitan Detroit. Clayton Environ. Consultants, Novi, MI

Rogers, D.T. 1997a. Surficial geologic map and cross section of the Rouge River watershed, Michigan. 1:62,500. River Rouge Natl. Wet Weather Demonstration Project (RRNWWDP), Wayne County, MI.

Rogers, D.T. 1997b. The influence of groundwater and surface water in Michigan's Rouge River watershed. p. 173-180. In Conjunctive use of water resources: Aquifer storage and recovery. Proc. of the Am. Water Resour. Assoc. Conf., Long Beach, CA. 22-26 Oct. 1997. AWRA, Middleburg, VA.

Rogers, D.T., and K.S. Murray. 1997. Occurrence of groundwater in metropolitan Detroit, U.S.A. p. 155-160. In Groundwater in the environment. Volume 1. Balkema Publ., Rotterdam, the Netherlands.

Shacklette, H.T., and J.G. Boerngen. 1984. Element concentrations in soils and other surficial materials of the conterminous United States. U.S. Geol. Survey Professional Paper 1270. U.S. Gov. Print. Office, Washington, DC.

Shuman, L.M. 1991. Chemical forms of micronutrients in soils. p. 113-144. In J.J. Mortvedt et al. (ed.) Micronutrients in agriculture. SSSA Book Ser. 4. SSSA, Madison, WI.

Stevenson, F.J. 1991. Organic matter-micronutrient reactions in soil. p. 145-186. In J.J. Mortvedt et al. (ed.) Micronutrients in agriculture. SSSA Book Ser. 4. SSSA, Madison, WI.

Thornton, I. 1991. Metal contamination of soil in urban areas. p. 124-139. In P.G. Bullock et al. (ed.) Soils in the urban environment. Blackwell Sci. Publ., Oxford.

United States Department of Health and Human Services. 1988. The nature and extent of lead poisoning in children in the United States: A report to Congress. Agency for Toxic Substances and Disease Registry (ATSDR), Atlanta.

USEPA. 1983. Test methods for evaluating solid waste (SW-486). USEPA, Washington, DC.

USEPA. 1998. Lead in your home: A parent's reference guide. EPA/ 747/B-98/002. Office of Prevention, Pesticides, and Toxic Substances, Washington, DC.

Wayne County Department of Environment. 1994. Rouge River Remedial Action Plan update. Wayne County Dep. of Environ., Detroit, MI. 